\title{
Neuropeptides in atopic dermatitis ${ }^{*}$
}

\author{
M. Cholis
}

\begin{abstract}
Abstrak
Sistem-sistem saraf, sistem imun, dan sistem kulit tidak berdiri sendiri-sendiri, tetapi berhubungan erat dan menggunakan bahasa yang sama dalam sitokin dan neurotransmitter. Dermatitis atopik (DA) dapat dicetuskan oleh beberapa faktor, misalnya stres emosi, garukan, dan keringat. Kaji ulang ini menyajikan tentang peranan neuropeptida (NP) pada DA. Pada DA, kelainan terdapat dalam distribusi beberapa jenis filamen saraf yang berhubungan dengan NP yang aktif. Serabut saraf meningkat. Serabut saraf untuk substance-P $(S P)$ dan calcitonin gene-related peptide (CGRP) positif. Konsentrasi SP kutan menurun, sedangkan vasoactive-intestinal polypeptide (VIP) meningkat. Pada pemeriksaan imunohistokimia, neuropeptide-Y (NPY) dijumpai pada sel dendrit epidermis pada lesi kulit DA. Namun serabut somatostatin (SOM) tidak dijumpai. Neuromediator memodulasi fungsi sel-sel kulit yang termasuk dalam sistem neuroimunokutan (SNIK), seperti endotel, sel kelenjar, fibroblas, sel epidermis, dan sel-sel imun. Kesimpulan: selama perjalanan penyakit DA, SNIK menjadi tidak stabil. Hasil penemuan menunjukkan bahwa NP ikut juga bertanggung jawab dalam memulai dan mempertahankan proses radang kulit dan menunjukkan keterlibatannya dalam patogenesis DA. Pelepasan NP oleh saraf kulit dapat menjelaskan bahwa stres emosi, garukan, dan keringat berperan pada kekambuhan DA. (Med J Indones 2001; 10: 197-200)
\end{abstract}

\begin{abstract}
The nervous system, the immune system, and the cutaneous system are not independent systems, but are closely associated and use the same language of cytokines and neurotransmitters. Atopic dermatitis (AD) is exacerbated by several factors, such as emotional stress, scratching and sweating. This review presents the role of neuropeptides $(N P)$ in $A D$. In $A D$, abnormalities occur in distribution of some types of neural filaments and in the associated active NP. Nerve fibre increases. Nerve fibres for substance-P (SP) and calcitonin gene-related peptide (CGRP) are positive. The cutaneous coneentration of SP decreases while vasoactive-intestinal polypeptide (VIP) increases. Immunohistochemical examination has revealed neuropeptide- $Y$ (NPY)-positive dendritic epidermal cells in AD lesions but no somatostatin (SOM) fibres. Neuromediators modulate functions of all cutaneous cellular types, which are all part of the neuroimmunocutaneous system (NCIS): endothelial cells, glandular cells, fibroblasts, epidermal cells and immune cells. Conclusion: during the course of AD, the NICS is destabilized. Evidence show that NP can also be responsible for the induction and maintenance of the cutaneous inflammation process and confirm an involvement in the pathogenesis of $A D$. Release of the NP by cutaneous nerve potentially explains the role of emotional stress, scratching and sweating in exacerbation of AD. (Med J Indones 2001; 10: 197-200)
\end{abstract}

Keywords: neuroimmunocutaneous system. neurotransmitter, neurogenic inflammation

Neuropeptides (NP) are small aminoacid compound contained in the neurons of the brain, spinal cord and peripheral nerves, where they act both as neurotransmitters and as neuromodulators. Neuroendocrine cells in the respiratory tract and in the skin contain several peptides. In addition, NP such as VIP has been identified in various inflammatory cells, including

Department of Dermato-Venereology School of Medicine Brawijaya University, Malang, Indonesia

* Presented at the $14^{\text {th }}$ Regional Conference of Dermatology (Asian-Australasian), July 26-30, 2000, Kuala Lumpur,

Malaysia eosinophils, mast cells, mononuclear and polymorphonuclear leukocytes. Neuromediators play a significant part in several disorders including diarrhoea, stomach ulcer and inflammatory disorders such as $\mathrm{AD} \cdot{ }^{1,2} \mathrm{AD}$ is a chronic inflammatory skin condition that frequently occurs in individuals with asthma and/or allergic rhinitis. Recent studies have elucidated how allergens; IgE, T cells, with skin homing capability, Langerhans cells, keratinocytes, eosinophils and mast cells may all contribute to the inflammatory process in $\mathrm{AD} .^{3}$ This review presents the recent advances in the role of NP in the pathogenesis of $\mathrm{AD}$. This review presents the recent advances in the role of NP in the pathogenesis of $\mathrm{AD}$. 


\section{THE NICS AND CUTANEOUS NEURO- MEDIATORS}

The nervous system, immune system and skin interact to allow function. These three systems are often considered as being independent from one another. However, the concept of the NICS is suggested because these three systems are closely linked anatomically and physiologically as well as during the course of certain pathologies. There are physical linkages such as cellular contacts between nerve fibres, cutaneous and immune cells; and chemical linkages such as cutaneous secretion of neuromediators and receptors of this neuromediator on cutaneous cells. And there are also functional linkages e.g. modulation of cutaneous and/or immune function by the neuromediators, and interactions between the skin, nervous system and immunity during the course of illness.

Nerve fibres are found in close association with important skin appendages such as blood vessels, hair follicles, sweat glands and other dermal component, particularly mast cells, leading to the conclusion that there are important interaction between the skin and the nervous system. ${ }^{4,5,6}$

Nerve fibres innervate the skin right up to the outermost layers of the epidermis. In the epidermis contact between nerve fibres and keratinocytes have also been described. In the dermis, direct contact between nerve fibres and mastocytes are observed. Like Langerhans cells, dermal dendritic cells have recently been observed in contact with axons.

Among the numerous neuromediators and neurohormones, about 20 have recently been demonstrated in human skin. Most are neuropeptides: SP, NPY, VIP, peptide-histidine-isoleucine, SOM, CGRP, neurokinins, gastrin-releasing peptide (GRP), galanin and bradykinin. Other are neurohormones.

Cutaneous neuromediators are sinthesized by nerve fibres and Merkel cells, and also by Langerhans cells, keratinocytes, melanocytes and all immune cells such as granulocytes, lymphocytes, monocytes, macrophages and mastocytes. Most of the cutaneous cells also possess receptor to the neuromediators. ${ }^{6,7}$

Skin cells are able to exert similar properties to those of nerve cells, such as the expression of markers of neuron or Schwann cells or receptors for neurotransmitters and the production of neuromediators. ${ }^{5,6}$

\section{FUNCTIONAL CONNECTIONS OF THE NICS}

NP have a variety of biologic actions, one of the most prominent being modulation of vascular tone and vascular permeability. SP, CGRP, natural killer antigen (NKA) and VIP are powerful vasodilators. NPY, on the other hand, is one of a new NP that cause an increase in vascular tone. The tachykinins SP and NKA have all been shown to increase vascular permeability. In contrast, NPY has been demonstrated to reduce the vascular permeability induced by SP.

Neuromediators exert effects on cutaneous cells. This action most often happen via receptors coupled with protein-G. Neuromediators modulate function of all cutaneous cellular types which are all part of the NICS. ${ }^{6,7}$

In contrast to the proinflammatory actions of SP, VIP has been shown to have various antiinflammatory actions. It inhibits NK activity, L-traffic (either through mast cell-mediated expression of endothelial adhesion molecules and/or by directly acting on endothelial cells). VIP also inhibits T proliferation. SP enhances while VIP inhibits IFN- $\gamma$ production from monocytes. SP and NKA induce secretion of IL-1, IL6 and TNF- $\alpha$ from monocytes and TNF and IL-1 from macrophages, while SP stimulates IL-2 production by T lymphocytes. ${ }^{5,8}$

Experimental studies have demonstrated that NP are involved in pruritus and nociception, in the regulation of blood flow and sweat secretion, in neurogenic inflammation and immunomodulation. As far as neurogenic inflammation is concerned, it is known from the classic model of axon reflex that a noxious stimulus applied to the skin generates an afferent impulse which travels upwards, orthodromically, to the point of ramification of the terminal branch of neurons, then descends into another branch with an antidromal direction leading to release of vasoactive substances from the nerve ending. This stimulus therefore initiates an orthodromic impulse, resulting in a sensation of pain or itch; whereas another impulse travels antidromically to the peripheral nerve endings with the release of NP which induce degranulation of mast cells and release of additional mediators and supplementary stimulation of nerve endings. Some NP can directly induce vasodilation. Moreover, the neurotoxin capsaicin can prevent aspects of classic neurogenic inflammation, such as antidromic vasodilation and neurogenic plasma extravasation from mustard oil application. NP antagonists may reduce neurogenic inflammatory responses. Moreover, the 
trophic activity of NP has been supported by both invivo and invitro experimental findings. For instance it has been shown that VIP but not SP is mitogenic for human keratinocytes. ${ }^{5,8}$

It is apparent from both invitro and invivo studies that NP exert their biologic effects through activation of specific cellular receptors. SP interacts preferentially with receptor of the NK-1 subclass. VIP receptors have been identified in the nose and lung. They are detectable in high density in vascular smooth muscle and in airway smooth muscle of large airways. They have also been found in epithelial cells, submucosal glands, and arterial and sinusoidal vessels of the nasal mucosa. In the skin it was able to demonstrate the presence of SP receptors in dermal and epidermal structures, and that keratinocytes bear VIP receptors. ${ }^{5,8}$

\section{NEUROPEPTIDES IN ATOPIC DERMATITIS}

Itch is the major symptom of $\mathrm{AD}$. It is known that itch in $\mathrm{AD}$ is exacerbated by several factors, such as emotional stress, scratching and sweating. Moreover, looking at several aspects of the pathophysiology of $\mathrm{AD}$ and at the function of the NP, interesting similarities can be observed. This data could support the hypothesis of a possible involvement of a neurogenic component in the pathogenesis of $\mathrm{AD}$. To address this issue, several studies have been performed on skin reactivity to NP as well as that on distribution, localization and skin levels of several NP.

In $\mathrm{AD}$, neurocutaneous alterations are observed. Nerve fibre density increases. It involves an increase of nerve fibres positive for SP and CGRP, while adrenergic innervation decreases, and SOM-immunoreactive nerve fibres disappear. Distribution of dermal and immunoreactive epidermal cells for SOM is highly disrupted, whereas NPY immuno-reactive dendritic cells appear in the epidermis. The cutaneous concentration of SP decreases while the concentration of VIP increases. This seems secondary to inflammation as SP is generally a stimulator of immune function, while VIP is generally an immune suppressor. ${ }^{6,10}$

Blood level of prolaction are increased during exacerbations of AD. Prolactin is in fact a socalled stress hormone since acute physical or behavioral stressor induce a rapid and significant increase in prolactin levels.
NP from sensory neuron are released following various stimuli. Synthetic cationic polypeptides, polyL-lysine and poly-L-arginine, are included among the stimuli that can activate sensory $\mathrm{C}$-fibres. Injection of $\mathrm{SP}$ into skin produces a wheal and flare reaction and is associated with mast cell degranulation and granulocyte infiltration. This inflammatory cell infiltrate includes eosinophils and neutrophils and results from both mast cell mediator release and vascular endothelial cell activation. ${ }^{11}$

Different amount of SP, NKA, VIP and CGRP are injected intradermally into the normal appearing skin of the back of $\mathrm{AD}$ patients allergic respiratory patients and healthy non-atopic subjects. Areas of flare and wheal were calculated at different times, using an automatic image analyzer. Responses were evaluated in relation to the dose injected and to the time after injection. No differences in wheal and flare reactivity between respiratory atopics and healthy controls were observed, whereas a significantly reduced flare and wheal response was noted in $A D$ patients when challenged with some NP such as SP. Dose response curve and time-course experiments showed the same behavior for $\mathrm{AD}$ patients and controls, but with a lower profile for $\mathrm{AD}$ patients. ${ }^{12}$

Among several explanations, it hypothesized a higher availability of NP in $\mathrm{AD}$ (tachiphylaxis) and/or an abnormal sensitivity of mast cells and blood vessels.

Similar results have been confirmed by other groups suggesting that a NP dysregulation could be operating in AD. Interestingly nerve fibres invaded by mast cell can be observed in AD skin. These results indicate that the imbalance of SP and VIP could reflect different roles of these NP as modulatory agents in AD skin lesions. It should be noted that SP and VIP exert diverse activities also in the immune system. The former being more stimulatory, whereas the latter acts as an inhibitory molecule. Moreover, high levels of VIP have also been detected in irritant and allergic contact dermatitis and in psoriasis. According to this data, it suggest that NP play a role in the pathogenesis of some skin diseases including allergic diseases and $\mathrm{AD},{ }^{5,6,13}$

\section{CONCLUSION}

During the course of AD the NICS is destabilized. Evidence show that NP can also be responsible for the induction and maintenance of the cutaneous 
inflammation process and confirm an involvement in the pathogenesis of AD. Release of the NP by cutaneous nerve potentially explain the role of emotional stress and scratching and sweating in exacerbating cutaneous inflammation in AD.

\section{REFERENCES}

1. Reilly DM, Ferdinando D, Johnson C, Shaw C, Buchanan $\mathrm{KD}$, Green MR. The epidermal nerve fibre network: characterization of nerve fibres in human skin by confocal microscopy and assessment of racial variations. British J of Dermatol. 1997; 137:163-70.

2. Lotti T, Hautmann G, Panconesi E. Neuropeptides in skin. J Am Dermatol. 1995; 33:482-96.

3. Boguniewicz M, Leung DYM. Atopic dermatitis. In: Leung DYM, Greaves MW, eds. Allergic Skin Disease. Marcel Dekker Inc., 2000: 120-30.

4. Cholis M. The neuroimmunocutaneous system: Role in the atopic dermatitis pathogenesis. In: Agusni I, Barakbah J, Sukanto H, Pohan SS, Lumintang H, Soejoso S, et al Eds. Perkembangan Penyakit Kulit \& Kelamin di Indonesia Menjelang Abad 21. Surabaya: Airlangga University Press, 1999; 1:15-8.

5. Gianetti A. Neuropeptides in atopic dermatitis. In: Wuthrich B ed. The atopy syndrome in the third millennium. Basel, Karger, New York: Curr Probl Dermatol. 1999; 28:51-5.

6. Misery L. Skin, immunity and the nervous system. British J of Dermatol. 1997; 137:843-50.

7. Bhardwaj RS, Luger TA. Propiomelanocortin production by epidermal cells: evidence for an immune neuroendocrine network in the epidermis. Arch Dermatol Res 1994; 287:85-90.

8. Girolomoni G, Tigelaar RE. Capsaicin sensitive primary sensory neurons are potent modulators of murine delayedtype hypersensitivity reactions. J Immunol 1990; 145: 1105-12.

9. Giannetti A, Girolomoni G. Skin reactivity to neuropeptides in atopic dermatitis. British J of Dermatol 1989; 121:681-8.

10. Cooper KD. Atopic dermatitis: recent trends in pathogenesis and therapy. J Invest Dermatol 1994; 102: 128-37.

11. Leiferman KM, Gleich GJ. The role of eosinophils in atopic dermatitis. In: Leung DYM ed. Atopic dermatitis : from pathogenesis to treatment. New York: Springer, RG Landes Co, 1996: 145-73.

12. Pincelli C, Fantini F, Massimi P, Girolomoni G, Seidenari $S$, Giannetti A. Neuropeptides in skin from patients with atopic dermatitis : an immunohistochemical study. British J of Dermatol 1990; 122:745-50.

13. Giannetti A, Fantini F, Cimitan A, Pincelli C. Vasoactive intestinal polypeptide and substance $\mathrm{P}$ in the pathogenesis of atopic dermatitis. Acta Derm-Venereol. (Stockh). 1992; (Suppl. 176):90-2. 